Al Maal : Journal of Islamic Economics and Banking

http://jurnal.umt.ac.id/index.php/jieb

E-ISSN : $2580-3816$

Vol : No 1 Vol 2 Bulan Januari Tahun 2020

Hlm : $187-206$

DOI : $\quad 10.31000 /$ almaal.v1i2.1934

\title{
Model Pengembangan Industri Kreatif Berbasis Syariah Di Provinsi Banten
}

\author{
Tri Harjawati ${ }^{1 *}$ \\ ${ }^{1}$ FITK UIN Syarif Hidayatullah Jakarta, Indonesia, \\ *tri.harjawati@uinjkt.ac.id
}

\begin{abstract}
This research is about the development of sharia-based industries in Banten Province. The goal is to find out how it's developed and Development Model. The method used descriptive qualitative, data sources obtained from primary and secondary data. Technical analysis of data uses the interactive analysis model of Miles and Huberman. The results of the study indicate that the Development of Sharia-Based Creative Industries in Banten Province is still in the stage of drafting regulations and policies for Halal industrial zones. But indirectly the implementation technique has been running for the culinary and fashion sector (Muslim clothes). However, for future targets, the Development of Sharia-Based Creative Industries is more towards empowering Islamic boarding schools through entrepreneurs so they can create santripreneur. It's can become centers of product excellence and centers of Islamic civilization. The Sharia-based Creative Industry Development Model in Banten Province is the form of buildings consisting of foundations, buildings and taps based on Islamic sharia boundaries. For the foundation in the form of creative beings, training can increase knowledge and creativity and the pillars consist of Industry, Technology, Natural Resources, Institutions and Financial Institutions. Tap here is the main actor, which consists of scholars/ communities, business people, and localgovernment.
\end{abstract}

Keywords : Sharia Marketing Mix; Halal Label; Purchase Decision

\begin{abstract}
ABSTRAK
Penelitian ini tentang perkembangan industri berbasis syariah di Propinsi Banten. Tujuannya yaitu untuk mengetahui bagaimana perkembangannya dan Bagaimana Model Pengembangannya. Metode yang digunakan yaitu kualitatif deskriptif, sumber data diperoleh dari data primer dan sekunder. Teknis analisis data menggunakan model analisis interaktif Miles dan Huberman (Sugiono, 2012:301). Hasil Penelitian menunjukkan bahwa Perkembangan Industri Kreatif Berbasis Syariah di Propinsi Banten masih dalam tahap penyusunan rancangan regulasi dan kebijakan kawasan industri Halal. Namun secara tidak langsung teknik pelaksanaannya sudah berjalan untuk sektor kuliner dan fashion (baju muslim). Hanya saja mereka tidak memiliki label halal serta belum ada regulasi yang memayunginya. Namun, untuk target kedepannya, Pengembangan Industri Kreatif Berbasis Syariah lebih ke arah pemberdayaan pondok pesantren melalui entrepreneur sehingga dapat menciptakan santripreneur. Sehingga nantinya, pondok pesantren bisa menjadi pusat unggulan produk dan pusat peradaban Islam di Provinsi Banten. Sedangkan Model Pengembangan Industri Kreatif berbasis syariah di Provinsi Banten berbentuk bangunan yang terdiri dari pondasi, bangunan, dan tap yang berdasarkan pada batasan-batasan syariat islami. Untuk Pondasinya berupa insan kreatif, melalui pelatihan-pelatihan dalam rangka meningkatkan pengetahuan dan kreatifitas. Sedangkan pilar utamanya terdiri dari Industri, Teknologi, Sumberdaya Alam, Kelembagaan, dan Lembaga Keuangan. Tap disini adalah aktor utama, yang terdiri dari cendikiawan/ masyarakat, pelaku bisnis, dan pemerintah daerah.
\end{abstract}

Kata kunci : Industri Kreatif Syariah; Model Pengembangan; Provinsi Banten 


\section{Pendahuluan}

Industri kreatif saat ini tengah menjadi trending topic dunia. Bahkan, banyak negara mulai sadar dan menjadikan sektor ini menjadi sektor prioritas pembangunannya. Selain itu, sektor ini juga menjadi alternatif tumpuan di tengah persoalan anjloknya harga minyak yang merembet ke sektor-sektor lainnya. Industri kreatif secara tidak langsung akan memberikan manfaat bagi suatu negara yaitu memberikan percepatan pertumbuhan ekonomi, menciptakan lapangan kerja dan meningkatkan kesejahteraan masyarakat. Di Indonesia hingga tahun 2016, total pendapatan dari industri ekonomi kreatif mencapai Rp 642 Trillun atau mencapai 7,05 persen dari total produk domestik bruto (PDB) Indonesia, namun dari sekian banyak industri kreatif hanya ada 3 industri kreatif yang memberikan kontribusi paling besar yaitu Kontribusi terbesar berasal dari Usaha Kuliner sebanyak 32,4 persen, Mode 27,9 persen, dan Kerajinan 14,88 persen (Abdur Rohim, 2016).

Padahal, Daya saing industri kreatif di Indonesia dapat di identifikasi berdasarkan tujuh dimensi utama yaitu sumber daya kreatif, sumber daya pendukung, industri, pembiayaan, pemasaran, infrastruktur dan teknologi, serta kelembagaan. Bila dipetakan berdasarkan tujuh dimensi tersebut, rata-rata daya saing 15 subsektor industri kreatif masih relatif rendah. Hal ini disebabkan oleh Pembiayaan yang dinilai sulit untuk dipenuhi oleh pelaku sektor industri kreatif, dikarenakan belum bankable, high risk high return, cash flow yang fluktuatif, serta aset yang bersifat intangible. Selain itu, Kelembagaan juga dinilai belum meningkatkan industri kreatif secara signifikan, hal ini dilihat dari regulasi yang ada kurang mendorong pengembangan industri kreatif. Selain itu, partisipasi pemangku kepentingan yang terbilang rendah, karena kurang mempertimbangkan kreativitas dalam pembangunan nasional, serta rendahnya partisipasi aktif dalam fora internasional serta apresiasi terhadap orang, karya, wirausaha, dan usaha kreatif lokal.

Model pengembangan ekonomi kreatif di Indonesia selama ini menggunakan triple-helix, dimana memerlukan sinergi dan kemitraan antara tiga faktor utama: pemerintah, swasta, dan intelektual (tim ahli dari kalangan akademisi dan publik). Dari segi Pemerintah, sikap pemerintah terhadap industri kreatif dinilai belum berpihak karena mereka masih dilanda berbagai kesulitan. Seperti yang di ungkapkan oleh Ajib Hamdani Ketua HIPMI Tax Center dalam acara Forum Dialog HIPMI ke-37 di Menara Bidakara 2 Jakarta Selasa (15/3/2016), yang menyatakan bahwa "Mereka sangat membutuhkan skema permodalan yang lebih mudah. Namun, mereka yang baru memulai usaha sering terkendala permodalan. Tak hanya itu saja, mereka juga dikenakan pajak PPn, terus ditambah lagi $\mathrm{PPh}$ badan. Ini tentu memberatkan dan perlakuannya harus dibedakan. Kalau bisa gak bayar pajak, kenapa harus bayar?" (HIPMI, 2016). Dari pernyataan diata, jelas terlihat bahwa persoalan yang di hadapi oleh Industri Kreatif saat ini adalah kaitannya dengan aspek permodalan dan aspek perpajakan.

Kaitannya dengan permodalan, penulis pernah meneliti bagaimana skema pembiayaan bagi Industri Kreatif di Kota Tangerang Selatan dan hasilnya menunjukkan bahwa pemerintah sudah memfasilitasi Industri kreatif untuk memperoleh bantuan permodalan dari lembaga pembiayaan yang sudah bekerja sama dengan pemerintah Kota Tangerang Selatan (Bank BNI, Bank BRI, dan Bank BJB). Namun, hal ini belum maksimal terlihat dari jumlah keseluruhan industri kuliner yang terdaftar di Dinas Perkoperasian dan UMKM Kota Tangerang Selatan, ada sekitar 7.547 UKM dari total jenis industri yang ada yaitu 20.671 (Tri Harjawati, 2016). Tetapi dari total tersebut yang 
memperoleh Fasilitas Sertifikasi Halal, PIRT, dan HKI oleh Dinas Perindustrian dan Perdagangan Kota Tangerang Selatan, hanya berjumlah 164 IKM dan lebih mirisnya hanya 12 IKM yang bisa dianggap unggul dan perlu mendapat perhatian untuk dikembangkan lebih jauh oleh Pemerintah Kota Tangerang Selatan (Tri Harjawati, 2016).

Tangerang selatan merupakan bagian wilayah dari Propinsi Banten. Dalam penelitian ini, penulis menambah fokus penelitian untuk Wilayah Propinsi Banten, hal ini di karenakan propinsi banten memiliki potensi yang jauh lebih besar untuk di kaji kaitannya dengan industri kreatif. Dengan demikian, perkembangan dan program kerja tentang industri kreatif di Propinsi Banten secara tidak langsung akan mempengaruhi kemajuan semua industri kreatif yang berada di kota-kota yang ada di wilayah Propinsi Banten. Sehingga keberhasilan dan kemajuan ekonominya merupakan keberhasilan dan kemajuan ekonomi bagi kota-kota di wilayahnya. Ukuran kemajuan ekonomi suatu wilayah akan terlihat dari banyaknya jumlah industri kreatif yang berada di wilayah tersebut. Karena dengan banyaknya jumlah industri kreatif, maka jumlah pengangguran akan terserap sehingga akan menambah tingkat pendapatan penduduk di wilayah tersebut.

Hal diatas, diperkuat oleh pernyataan Deputi Gubernur Bank Indonesia, Rosmaya Hadi, yang menyatakan bahwa Provinsi Banten berada pada urutan kedua tingkat pengangguran terbesar di wilayah Indonesia (http://www.potrettangerang.id). Dari pernyataan diatas, jelaslah Provinsi Banten memiliki tantangan yang besar dalam mengurangi ketimpangan angka pengangguran dan kemiskinan. Salah satu cara yang harus dilakukan adalah adanya pergerakan usaha pada industri kreatif. Sehingga, diharapkan dengan adanya industri kreatif dapat mengurangi angka tersebut dan bahkan dapat meningkatkan perekonomian bagi wilayah Provinsi Banten.

Provinsi Banten terkenal dengan sejarah ke Islamannya, sehingga pemerintah Provinsi Banten berkewajiban melestarikan budaya ke islaman yang belakangan mulai terpinggirkan oleh budaya barat. Salah satunya melalui pergerakan roda perekenomian masyarakat yang berpedoman pada kearifan lokal berbasis syariat atau biasa disebut sebagai Ekonomi syariah. Ekonomi syariah tidak hanya bergerak di perbankan saja, melainkan bisa juga bergerak di industri kreatif berbasis syariah seperti fashion atau busana, film, dan budaya islam. Tujuan program usaha kreatif berbasis syariah yaitu akan tercipta para pengusaha muslim yang kreatif yang menjalankan sistem ekonomi, perdagangan sesuai prinsip syariah yang berkeadilan dengan tujuan maslahat ummat bersama, terutama dikalangan anak muda. Sehingga, dengan adanya penerapan industri kreatif berbasis syariah, di harapkan Provinsi Banten akan mampu mandiri dan mampu bertahan dalam menghadapi krisis global. Dari pemaparan diatas, maka peneliti merasa tertarik untuk meneliti lebih lanjut tentang industri berbasis syariah di Wilayah Propinsi Banten..

\section{KAJIAN LITERATUR Pengertian Industri Kreatif}

Industri Kreatif berasal dari kata In dustri dan Kreatif. Industri berarti memanfaatkan kreativitas, ketrampilan serta bakat individu untuk menciptakan kesejahteraan serta lapangan pekerjaan melalui penciptaan dan pemanfaatan daya kreasi dan daya cipta individu tersebut. Sedangkan Kreatif merupakan ide yang memunculkan berbagai macam inovasi yang kreatif. 
Pengertian lainnya yaitu Menurut Departemen Perdagangan RI, Industri Kreatif yaitu Industri yang berasal dari pemanfaatan kreativitas, ketrampilan serta bakat individu untuk menciptakan kesejahteraan serta lapangan pekerjaan melalui penciptaan dan pemanfaatan daya kreasi dan daya cipta individu tersebut (Departemen Perdagangan Republik Indonesia, 2008). Sedangkan menurut UK DCMS Task Force, "Creative Industries as those industries which have their origin in individual creativity, skill \& talent, and which have a potential for wealth and job creation through the generation and exploitation of intellectual property and content". Artinya industri kreatif merupakan industri-industri yang berasal dari kreatifitas, ketrampilan dan bakat individu, serta yang memiliki potensi untuk penciptaan kesejahteraan dan pekerjaan melalui penciptaan dan eksploitasi daya cipta dan kandungan intelektual seseorang.

\section{Jenis Industri Kreatif}

Industri kreatif dapat dikelompokkan menjadi 15 subsektor. Menurut Departemen Perdagangan Republik Indonesia dalam buku Pengembangan Industri Kreatif Menuju Visi Ekonomi Kreatif 2025, ke 15 subsektor industri kreatif Indonesia adalah : Periklanan (advertising), Arsitektur, Pasar Barang Seni, Kerajinan (craft), Desain, Fesyen (fashion), Video, Film dan Fotografi, Permainan Interaktif (game), Musik, Seni Pertunjukan (showbiz), Penerbitan dan Percetakan, Layanan Komputer dan Piranti Lunak (software), Televisi \& Radio (broadcasting), Riset dan Pengembangan (R\&D), dan Kuliner.

\section{Dampak Pengembangan Industri Kreatif di Indonesia}

Salah satu alasan dari pengembangan industri kreatif adalah adanya dampak positif yang akan berpengaruh pada kehidupan sosial, iklim bisnis,peningkatan ekonomi, dan juga berdampak para citra suatu kawasan tersebut. Dalam konteks pengembangan ekonomi kreatif pada kota-kota di Indonesia, industri kreatif lebih berpotensi untuk berkembang pada kota-kota besar atau kota-kota yang telah "dikenal". Hal ini terkait dengan ketersediaan sumber daya manusia yang handal dan juga tersedianya jaringan pemasaran yang lebih baik dibanding kota-kota kecil. Namun demikian, hal itu tidak menutup kemungkinan kota-kota kecil di Indonesia untuk mengembangkan ekonomi kreatif. Bagi kota-kota kecil, strategi pengembangan ekonomi kreatif dapat dilakukan dengan memanfaatkan landmark kota atau kegiatan sosial seperti festival sebagai venue untuk mengenalkan produk khas daerah (Susan, 2004). Hal ini dijabarkan seperti pada Gambar 2.1

Gambar 1 Bagan Dampak Pengembangan Ekonomi Kreatif di Indonesia

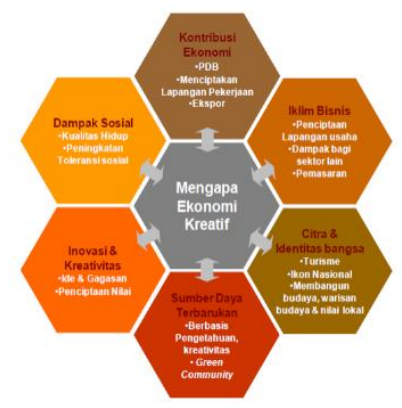

Sumber : Laporan Akhir Penyusunan Profil Kebijakan Pariwisata dan Ekonomi Kreatif 
Menurut Departemen Perdagangan, (2007) ada beberapa arah dari pengembangan industri kreatif ini, seperti pengembangan yang lebih menitikberatkan pada industri berbasis : (1) lapangan usaha kreatif dan budaya (creative cultural industry); (2) lapangan usaha kreatif (creative industry) atau (3) Hak Kekayaan Intelektual seperti hak cipta (copyright industry).

\section{Pengertian Ekonomi Kreatif}

Ekonomi kreatif adalah sebuah konsep yang menempatkan kretivitas dan pengetahuan sebagai aset utama dalam menggerakkan ekonomi. Konsep ini telah memicu ketertarikan berbagai negara untuk melakukan kajian seputar Ekonomi Kreatif dan menjadikan Ekonomi Kreatif model utama pengembangan ekonomi. Indonesia Kreatif (http://indonesiakreatif.net/creative-economy).

Sedangkan dalam definisi yang berbeda, dikemukakan bahwa ekonomi kreatif pada hakikatnya adalah kegiatan ekonomi yang mengutamakan pada kretivitas berpikir untuk menciptakan sesuatu yang baru dan berbeda yang memiliki nilai dan bersifat komersial. Berikut telah dikemukakan oleh UNCTAD dalam Creative Economic Report (2008:3) "Creativity in this context refers to formulation of new ideas and to the application of these ideas to produce original works of art and cultural products, functional creation, observable in the way it contribuates to enteurpreneurship, fosters innovation, enchaces productivity and promotes economic growth". (UNCTAD :2008)

Istilah "Ekonomi Kreatif" mulai dikenal secara global sejak munculnya buku "The Creative Economy : How People Make Money from Ideas" (2001) oleh John Howkins. Howkins menyadari lahirnya gelombang ekonomi baru berbasis kreativitas setelah melihat pada tahun 1997 Amerika Serikat menghasilkan produk-produk Hak Kekayaaan Intelektual (HKI) senilai 414 millliar dollar yang menjadikan HKI ekspor nomor 1 Amerika Serikat. Howkins dengan ringkas mendefinisikan ekonomi kreatif, yaitu "The creation of value as a result of idea".

John Howkins menulis buku "Creative Economy : How People Make Money from Ideas". Ia mendefinisikan Ekonomi Kreatif sebagai kegiatan ekonomi dimana input dan outputnya adalah gagasan atau dalam satu kalimat yang singkat, esensi dari kreativitas adalah gagasan. Maka dapat dibayangkan bahwa hanya dengan modal gagasan, seseorang yang kreatif dapat memperoleh penghasilan yang relatif tinggi. Tentu saja yang dimaksud dengan gagasan disini adalah karya orisinal dan dapat diproteksi oleh HKI.

Dalam sebuah wawancara oleh Donna Ghelfi dari World Intellectual Property Organization (WIPO) ditahun 2005, John Howkins secara sederhana menjelaskan Ekonomi Kreatif yang disarikan sebagai berikut: " Kegiatan ekonomi dalam masyarakat yang menghabiskan sebagian besar waktunya untuk menghasilkan ide, tidak hanya melakukan hal-hal yang rutin dan berulang. Karena bagi masyarakat ini, menghasilkan ide merupakan hal yang harus dilakukan untuk kemajuan.

Studi Ekonomi Kreatif terbaru yang dilakukan United Nations Conference on Trade and Development (UNCTAD) pada tahun 2010 mendefinisikan Ekonomi Kreatif sebagai "An evolving concept based and creative assets potentially generating economic growth and development". Dengan penjabaran lebih lanjut sebagai berikut : 
- Mendorong peningkatan pendapatan, penciptaan pekerjaan, dan pendaptan ekspor dan impor sekaligus mempromosikan kepedulian sosial, keragaman budaya dan pengembangan manusia.

- Menyertakan aspek sosial, budaya, dan ekonomi dalam pengembangan teknologi, Hak Kekayaan Intelektual, dan pariwisata.

- Kumpulan aktivitas ekonomi berbasiskan pengetahuan dengan dimensi pengembangan dan keterhubungan lintas sektorat pada level ekonomi mikro dan makro secraa keseluruhan.

- Suatu pilihan strategi pengembagan yang membutuhkan tindakan lintas kementerian dan kebijakan yang inovatif dan multi disiplin.

- Di jantung Ekonomi Kreatif terhadap industri kreatif.

Dalam jurnal kajian Lemhanas RI Edisi 14 mendefinisikan Ekonomi Kreatif : “ Ekonomi Kreatif merupakan pengembangan ekonomi berdasarkan keterampilan kreativitas, dan bakat individu untuk menciptakan daya kreasi dan daya cipta individu yang bernilai ekonomis, sehingga menitikberatkan pada pengembangan ide dalam menghasilkan nilai tambah".

Konsep Ekonomi Kreatif ini juga semkain memberi harapan yang lebih optimistik ketika seorang pakar dibidang Ekonomi, Dr. Richard Florida dari Amerika Serikat penulis buku "The Rise of Creative Class" dan "Cities and the creative cost class" menyatakan : "Seluruh umat manusia adalah kreatif, apakah ia seorang pekerja dipabrik kacamata atau seorang remaja jalanan yang telah membuat musik hip-hop. Namun perbedaannya adalah pada statusnya (kelasnya), karena ada individu-individu yang secara khusus bergelut dibidang kreatif dan mendapat faedah ekonomi secara langsung dari aktivitas tersebut. Maka tempat di kota-kota yang mampu menciptakan produk-produk baru inovatif tercepat, dapat dipastikan sebagai pemenang kompetisi di era ekonomi kreatif ini".

Pendapat senada juga diutarakan oleh Robert Lucas, pemenag Nobel dibidang ekonomi yang menyatakan bhawa kekuatan yang menggerakkan pertumbuhan dan pembangunan ekonomi kota atau daerah dapat dilihat dari tingkat produktivitas klaster orang-orang bertalenta dan kreatif yang mengandalkan kemampuan ilmu pengetahuan yang ada pada dirinya. Dalam hal ini, Ekonomi Kreatif sering dilihat sebagai sebuah konsep yang memayungi juga konsep lain yang populer diawal abad ke 21 ini, Industri Kreatif sendiri sebenarnya merupakan sebuah konsep yang telah muncul lebih dahulu sebelum munculnya konsep ekonomi kreatif.

Ekonomi kreatif adalah pemanfaatan cadangan sumber daya yang bukan hanya terbarukan, bahkan tak terbatas, yaitu ide, gagasan, bakat atau talenta dan kretivitas. Nilai ekonomi dari suatu produk atau jasa di era kreatif tidak lagi ditentukan oleh bahan baku atau sistem produksi seperti pada era industri, tetapi lebih pada pemanfaatan kreativitas dan penciptaan inovasi melalui perkembangan tekonologi yang semakin maju. Industri tidak dapat lagi bersaing di pasar global dengan hanya mengandalkan harga atau kualitas produk saja, tetapi harus bersaing berbasiskan inovasi, kreativitas dan imajinasi.

Departemen Perdagangan Republik Indonesia (2008) merumuskan ekonomi kreatif sebagai upaya pembangunan ekonomi secara berkelanjutan melalui kreativitas dengan iklim perekonomian yang berdaya saing dan memiliki cadangan sumber daya 
yang terbarukan. Definisi yang lebih jelas disampaikan oleh UNDP (2008) yang merumuskan bahwa ekonomi kreatif merupakan bagian integratif dari pengetahuan yang bersifat inovatif, pemanfaatan teknologi secara kreatif, dan budaya. Seperti dijelaskan pada Gambar 2.2 :

Gambar 2 Bagan rumusan ekonomi kreatif menurut UNDP (2008)

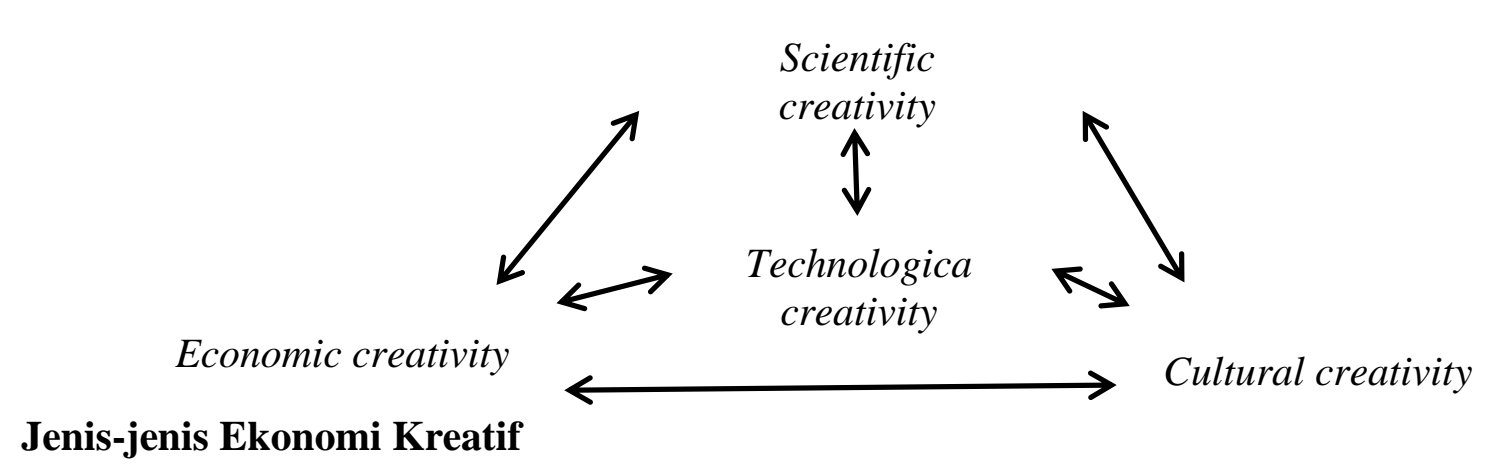

Lingkup kegiatan dari ekonomi kreatif dapat mencakup banyak aspek. Departemen Perdagangan RI (2008) mengidentifikasi setidaknya ada 14 sektor yang termasuk dalam ekonomi kreatif, yaitu, Periklanan, Arsitektur, Pasar barang seni. Kerajinan (handicraft), Desain, Fashion, Film, video, dan fotograf, Permainan interaktif, Musik, Seni pertunjukan, Penerbitan dan percetakan, Layanan komputer dan piranti lunak, Radio dan televisi, Riset dan pengembangan

\section{Hubungan Ekonomi Kreatif dengan Industri Kreatif}

Ekonomi Kreatif dalam hubungannya dengan Industri Kreatif adalah kegiatan ekonomi yang mencakup industri dengan kreativitas sumber daya manusia sebagai aset utama untuk menciptakan nilai tambah ekonomi. Dr. Mari Eka Pangestu dalam Konvensi Pengembangan Ekonomi Kreatif 2009-2015 menyebutkan beberapa alasan mengapa industri kreatif perlu dikembangkan di Indonesia, antara lain:

- Memberikan kontibusi ekonomi yang signifikan

- Menciptakan iklim bisnis yang positif

- Membangun citra dan identitas bangsa

- Berbasis kepada sumber daya yang terbarukan

- Menciptakan inovasi dan kreativitas yang merupakan keunggulan kompetitif suatu bangsa

- Memberikan dampak sosial yang positif

Di Indonesia sendiri, khususnya didalam peraturan perundang-undangan yang berlaku tidak digunakan istilah Industri Kreatif melainkan Ekonomi Kreatif (EK). Adapun yang dimaksud dengan EK menurut Diktum Pertama Instruksi Presiden No. 6 Tahun 2009 tentang Pengembangan Ekonomi Kreatif adalah: “... kegiatan ekonomi berdasarkan kreativitas, keterampilan dan bakat individu untuk menciptakan daya kreasi dan daya cipta individu bernilai ekonomis dan berpengaruh terhadap kesejahteraan masyarakat Indonesia. 


\section{Ekonomi Kreatif dan Pembangunan Ekonomi}

Pertumbuhan ekonomi adalah proses terjadi kenaikan produk nasional bruto riil atau pendapatan nasional riil. Jadi perekonomian dikatakan tumbuh atau berkembang bila terjadi pertumbuhan output riil. Output total riil suatu perekonomian bisa juga tetap konstan atau mengalami penurunan sepanjang waktu. Pertumbuhan ekonomi adalah proses kenaikan output per kapita dalam jangka panjang. Ada tiga aspek yang perlu diperhatikan yaitu proses, output perkapita dan jangka panjang :

Pertama, pertumbuhan ekonomi adalah suatu proses, bukan suatu gambaran ekonomi pada suatu saat. Disini dapat dilihat aspek dinamis dari suatu perekonomian, yaitu melihat bagaimana perekonomian berkembang atau berubah dari waktu ke waktu.

Kedua, pertumbuhan ekonomi berkaitan dengan kenaikan output perk apita. Ada dua sisi hal yang perlu diperhatikan yaitu sisi output totalnya dan sisi jumlah penduduknya. Output per kapita adalah output total dibagi jumlah penduduk. Jadi proses kenaikan output per kapita harus dianalisis dengan jalan melihat apa yang terjadi dengan output total di satu pihak, dan jumlah penduduk di lain pihak.

Ketiga, aspek yang ketiga dari definisi pertumbuhan ekonomi adalah perspektif jangka panjang. Kenaikan output per kapita selama satu atau dua tahun, yang kemudian dikuti dengan penurunan output per kapita bukan pertumbuhan ekonomi. Suatu perekonomian tumbuh apabila dalam jangka waktu yang cukup untuk mengalami kenaikan output perkapita.

Ada beberapa sumber strategis dan dominan yang menentukan pertumbuhan ekonomi tergantung bagaimana mengklasifikasikannya. Salah satu mengklasifikasikanya adalah menjadi faktor-faktor fisik dan faktor-faktor manajemen yang mempengaruh sumber-sumber tersebut. Meskipun mempunyai sumber untuk pertumbuhan yang kuantitasnya cukup banyak serta dengan kualitas tinggi tetapi bila manajemen penggunaannya tidak menunjang maka laju pertumbuhan ekonominya akan rendah. Faktor pertumbuhan berupa faktor-faktor sumber-sumber daya alami, kuantitas dan kualitas sumber daya manusia, jumlah barang-barang kapital dan teknologi. Keempat faktor ini disebut faktor-faktor penawaran dalam pertumbuhan ekonomi. Tersedianya lebih banyak dan lebih baik sumber-sumber alami dan manusia, barang kapital, serta tingkat pengetahuan teknologi yang lebih tinggi memungkinkan perekonomian memproduksi jumlah output lebih besar.

Teori pertumbuhan ekonomi bisa didefinisikan sebagai penjelasan mengenai faktor-faktor apa yang menentukan kenaikan output per kapita dalam jangka panjang, dan penjelasan mengenai bagaimana faktor-faktor tersebut interaksi satu sama lain, sehingga terjadi proses pertumbuhan. Satu hal yang perlu ditekankan sejak awal adalah bahwa di dalam ilmu ekonomi tidak hanya dapat satu teori pertumbuhan, tetapi terdapat banyak teori pertumbuhan. Sampai saat ini (dan masa mendatang) tidak ada suatu teori pertumbuhan yang menyeluruh dan lengkap dan yang merupakan satu-satunya teori pertumbuhan yang baku. Berbagai ekonom besar, sejak lahirnya ilmu ekonomi mempunyai panndangan atau persepsi yang tidak selalu sama mengenai proses pertumbuhan atu perekonomian. Sering kali pandangan atau persepsi ini sangat dipengaruhi keadaan atau peristiwa-peristiwa pada waktu ekonomi tersebut hidup. seringkali pula teori pertumbuhan seorang ekonorn dipengaruhi oleh ideologi yang dianut oleh ekonom, sehingga aspek-aspek yang ditonjolkan dalam teorinya mencerminkan 
kecenderungan idiologisnya Pembangunan ekonomi wilayah adalah suatu proses dimana pemerintah dan masyarakat mengelola sumberdaya yang ada dan membentuk suatu pola kemitraan antara pemerintah dengan sektor swasta untuk menciptakan suatu lapangan kerja baru dan merangsang perkembangan kegiatan ekonomi pertumbuhan ekonomi dalam wilayah tersebut. (Lincolin, 1999).

\section{Dampak Ekonomi Kreatif Terhadap Pertumbuhan Ekonomi}

Menurut Schumpeter pertumbuhan ekonomi adalah peningkatan output masyarakat yang disebabkan oleh semakin banyaknya jumlah faktor produksi yang digunakan dalam proses produksi masyarakat tanpa adanya perubahan "teknologi" produksi itu sendiri. Misalnya kenaikan output yang disebabkan oleh pertumbuhan stok modal tanpa perubahan teknologi produksi yang lama.

Sedangkan pembangunan ekonomi adalah kenaikan output yang disebabkan oleh inovasi yang dilakukan oleh para wiraswasta. Inovasi ini berarti perabaikan "teknologi" dalam arti luar, miasalnya penemuan produk baru, pembukaan pasar baru dsb. Inovasi tersebut menyangkut perbaikan kuantitatif dari system ekonomi itu sendiri yang bersumber dari kreatifitas para wiraswastanya. Kunci keberhasilan pembangunan ekonomi dan pengembangan bisnis terletak pada keunggulan modal manusia dalam membangun ekonomi kreatif di arus pengembangan ekonomi modern, melalui: investasi jangka panjang pada pendidikan, modernisasi infrastruktur informasi, peningkatan infastruktur untuk pengembangan kreatifitas dan kapabilitas inovasi, dan penciptaan lingkungan ekonomi yang kondusif untuk mendorong transaksi pasar yang lebih atraktif tetapi efisien.

\section{Manfaat Ekonomi Kreatif}

Manfaat ekonomi kreatif dinilai mampu mempertegas dan memperkaya identitas nasional Bangsa indonesia karena bisa memadukan ide, seni, dan inovasi berbasis teknologi dan budaya yang tumbuh di kalengan masyarakat lokal. Melalui dukungan ekonomi kreatif, bangsa kita memperoleh manfaat, yaitu pertumbuhan ekonomi yang prorakyat, pemanfaatan sumberdaya alam secara efektif serta penguatan identitas kultural yang justru akan mempertegas dan memperkaya identitas nasional bangsa kita sektor ekonomi kreatif sekaligus memiliki peran signifikan dalam mendorong penciptaan lapangan kerja dan meningkatkan kesejahteraan masyarakat. Selain itu mampu meningkatkan kemampuan teknologi tepat guna dan merupakan produk berbasis progreen.

\section{Pilar Utama Pengembangan Model Ekonomi Kreatif}

Dalam model pengembangan ekonomi kreatif terdapat 5 pilar yang perlu terus diperkuat sehingga industri kreatif dapat tumbuh dan berkembang. Kelima pilar ekonomi kreatif tersebut dapat dijabarkan sebagai berikut :

Industri. Merupakan bagian dari kegiatan masyarakat yang terkait dengan produksi, distribusi, pertukaran serta konsumsi produk atau jasa dari sebuah negara atau area tertentu.

Teknologi. Teknologi dapat didefinisikan sebagai suatu entitas baik material dan non material, yang merupakan aplikasi penciptaan dari proses mendal atau fisik untuk mencapai nilai tertentu. Dengan kata lain, teknologi bukan hanya mesin ataupun alat 
bantu yang sifatnya berwujud, tetapi teknologi ini termasuk kumpulan teknik atau metode-metode, atau aktivitas yang membentuk dan mengubah budaya. Teknologi ini akan merupakan enabler untuk mewujudkan kreativitas individu dalam karya nyata.

Sumber Daya. Sumber daya yang dimaksudkan disini adalah input yang dibutuhkan dalam proses penciptaan nilai tambah, selain ide atau kreativitas yang dimiliki oleh sumber daya insani yang merupakan landasan dari industri kreatif ini. Sumber daya meliputi sumber daya alam maupun ketersediaan lahan yang menjadi input penunjang dalam industri kreatif.

Institusi. Institusi dalam pilar pengembangan industri kreatif dapat didefinisikan sebagai tatanan sosial dimana termasuk di dalamnya adalah kebiasaan, norma, adat, aturan, serta hukum yang berlaku. Tatanan sosial ini bersifat informal - seperti sistem nilai, adat istiadat, norma - maupun formal dalam bentuk peraturan perundang-undangan.

Lembaga Intermediasi Keuangan. Lembaga ini berperan menyalurkan pendanaan kepada pelaku industri yang membutuhkan, baik dalam bentuk modal/ekuitas maupun pinjaman/kredit. Lembaga intermediasi keuangan merupakan salah satu elemen penting untuk menjembatani kebutuhan keunagan bagi pelaku dalam industri kreatif. Ekonomi Syariah

\section{Pengertian Ekonomi Syariah}

Ekonomi Syariah adalah suatu cabang ilmu pengetahuan yang berupaya untuk memandang, menganalisis, dan akhirnya menyelesaikan permasalahan-permasalahan ekonomi dengan cara-cara Islam, yaitu berdasarkan atas ajaran agama Islam, yaitu Al Qur'an dan Sunnah Nabi (P3EI, 2012:17)

Ekonomi syariah memiliki dua hal pokok yang menjadi landasan hukum sistem ekonomi syariah yaitu Al Qur'an dan Sunnah Rasulullah, hukum-hukum yang diambil dari kedua landasan pokok tersebut secara konsep dan prinsip adalah tetap (tidak dapat berubah kapanpun dan dimana saja). Berikut ini beberapa pengertian Ekonomi Syariah dari beberapa sumber buku:

Menurut Monzer Kahf dalam bukunya The Islamic Economy menjelaskan bahwa ekonomi Islam adalah bagian dari ilmu ekonomi yang bersifat interdisipliner dalam arti kajian ekonomi syariah tidak dapat berdiri sendiri, tetapi perlu penguasaan yang baik dan mendalam terhadap ilmu-ilmu syariah dan ilmu-ilmu pendukungnya juga terhadap ilmuilmu yang berfungsi sebagai tool of analysis seperti matematika, statistik, logika dan ushul fiqih (Al Arif, Nur dan Euis, $2010: 7$ )

M.A. Mannan mendefinisikan ilmu ekonomi syariah sebagai suatu ilmu pengetahuan sosial yang mempelajari masalah-masalah ekonomi rakyat yang diilhami oleh nilai-nilai islam (Mannan, $1992: 15$ )

Definisi ekonomi syariah berdasarkan pendapat Muhammad Abdullah Al-Arabi, Ekonomi Syariah merupakan sekumpulan dasar-dasar umum ekonomi yang kita simpulkan dari Al Qur'an dan As-sunnah, dan merupakan bangunan perekonomian yang kita dirikan di atas landasan dasar-dasar tersebut sesuai dengan tiap lingkungan dan masa. (Ahmad,dan Fathi, $1980: 11$ ) 


\section{Tujuan Ekonomi Syariah}

Tujuan Ekonomi Syariah selaras dengan tujuan dari syariat Islam itu sendiri (maqashid asy syari'ah), yaitu mencapai kebahagiaan di dunia dan akhirat (falah) melalui suatu tata kehidupan yang baik dan terhormat (hayyah thayyibah). Tujuan falah yang ingin dicapai oleh Ekonomi Syariah meliputi aspek mikro ataupun makro, mencakup horizon waktu dunia atau pun akhirat (P3EI, 2012:54).

Seorang fuqaha asal Mesir bernama Prof. Muhammad Abu Zahrah mengatakan ada tiga sasaran hukum Islam yang menunjukkan bahwa Islam diturunkan sebagai rahmat bagi seluruh umat manusia, yaitu (Rahman dan Afzalur, 1995: 84).

- Penyucian jiwa agar setiap muslim bisa menjadi sumber kebaikan bagi masyarakat dan lingkungannya.

- Tegaknya keadilan dalam masyarakat. Keadilan yang dimaksud mencakup aspek kehidupan di bidang hukum dan muamalah.

- Tercapainya maslahah (merupakan puncaknya). Para ulama menyepakati bahwa maslahah yang menjad puncak sasaran di atas mencakup lima jaminan dasar, yaitu: keselamatan keyakinan agama (al din), kesalamatan jiwa (al nafs), keselamatan akal (al aql), keselamatan keluarga dan keturunan (al nasl) dan keselamatan harta benda (al mal).

\section{Manfaat Ekonomi Syariah}

Apabila mengamalkan ekonomi syariah akan mendatangkan manfaat yang besar bagi umat muslim dengan sendirinya, yaitu (Muchlisin, 2016) :

- Mewujudkan integritas seorang muslim yang kaffah, sehingga islam-nya tidak lagi setengah-setengah. Apabila ditemukan ada umat muslim yang masih bergelut dan mengamalkan ekonomi konvensional, menunjukkan bahwa keislamannya belum kaffah.

- Menerapkan dan mengamalkan ekonomi syariah melalui lembaga keuangan islam, baik berupa bank, asuransi, pegadaian, maupun BMT (Baitul Maal wat Tamwil) akan mendapatkan keuntungan dunia dan akhirat. Keuntungan di dunia diperoleh melalui bagi hasil yang diperoleh, sedangkan keuntungan di akhirat adalah terbebas dari unsur riba yang diharamkan oleh Allah.

- Praktik ekonomi berdasarkan syariat islam mengandung nilai ibadah, karena telah mengamalkan syariat Allah.

- Mengamalkan ekonomi syariah melalui lembaga keuangan syariah, berarti mendukung kemajuan lembaga ekonomi umat Islam.

- Mengamalkan ekonomi syariah dengan membuka tabungan, deposito atau menjadi nasabah asuransi syariah berarti mendukung upaya pemberdayaan ekonomi umat. Sebab dana yang terkumpul akan dihimpun dan disalurkan melalui sektor perdagangan riil.

- Mengamalkan ekonomi syariah berarti ikut mendukung gerakan amar ma'ruf nahi munkar. Sebab dana yang terkumpul pada lembaga keuangan syariah hanya boleh disalurkan kepada usaha-usaha dan proyek yang halal. 


\section{Prinsip-prinsip Ekonomi Syariah}

Pelaksanaan ekonomi syariah harus menjalankan prinsip-prinsip sebagai berikut (Sudarsono dan Hendri, 2002: 105) :

- Berbagai sumber daya dipandang sebagai pemberian atau titipan dari Allah swt kepada manusia.

- Islam mengakui pemilikan pribadi dalam batas-batas tertentu.

- Kekuatan penggerak utama Ekonomi Syariah adalah kerja sama.

- Ekonomi Syariah menolak terjadinya akumulasi kekayaan yang dikuasai oleh segelintir orang saja.

- Ekonomi Syariah menjamin pemilikan masyarakat dan penggunaannya direncanakan untuk kepentingan banyak orang.

- Seorang muslim harus takut kepada Allah swt dan hari penentuan di akhirat nanti.

- Zakat harus dibayarkan atas kekayaan yang telah memenuhi batas (nisab).

- Islam melarang riba dalam segala bentuk.

Layaknya sebuah bangunan, sistem ekonomi syariah harus memiliki fondasi yang berguna sebagai landasan dan mampu menopang segala bentuk kegiatan ekonomi guna mencapai tujuan mulia. Berikut ini merupakan prinsip-prinsip dasar dalam ekonomi syariah, diantaranya adalah (Zainuddin, 2008: 125) :

- Tidak melakukan penimbunan (Ihtikar). Penimbunan, dalam bahasa Arab disebut dengan al-ihtikar. Secara umum, ihtikar dapat diartikan sebagai tindakan pembelian barang dagangan dengan tujuan untuk menahan atau menyimpan barang tersebut dalam jangka waktu yang lama, sehingga barang tersebut dinyatakan barang langka dan berharga mahal.

- Tidak melakukan monopoli. Monopoli adalah kegiatan menahan keberadaan barang untuk tidak dijual atau tidak diedarkan di pasar, agar harganya menjadi mahal. Kegiatan monopoli merupakan salah satu hal yang dilarang dalam Islam, apabila monopoli diciptakan secara sengaja dengan cara menimbun barang dan menaikkan harga barang.

- Menghindari jual-beli yang diharamkan. Kegiatan jual-beli yang sesuai dengan prinsip Islam, adil, halal, dan tidak merugikan salah satu pihak adalah jual-beli yang sangat diridhai oleh Allah swt. Karena sesungguhnya bahwa segala hal yang mengandung unsur kemungkaran dan kemaksiatan adalah haram hukumnya.

\section{Metode Penelitian}

Tempat Penelitian

Tempat penelitian yaitu di Provinsi Banten yang beralamat di Kawasan Pusat Pemerintahan Prov. Banten Jln. Brigjen K.H. Syam'un No. 5 Serang Telp: (0254) 200123 Fax: (0254) 200520. 


\section{Metode Penelitian}

Penelitian ini menggunakan metode kualitatif deskriptif yaitu penelitian yang dilakukan dengan cara mendeskripsikan masalah secara mendalam dari data-data yang ditemukan. Sumber data diperoleh dari data primer dan data sekunder. Data primer yaitu hasil wawancara dengan narasumber yang berasal dari Dinas Perindustrian dan Perdagangan Provinsi Banten dan Biro Bina Perekonomian SETDA Provinsi Banten, sedangkan data sekundernya yaitu Data tentang Laporan Akhir tentang Kebijakan dalam Menumbuhkan kembangkan Ekonomi Kreatif di Provinsi BantenTahun 2017, Laporan Akhir Penyusunan Profil Kebijakan Pariwisata dan Ekonomi Kreatif Tahun 2017, Laporan akhir Profil Kebijakan Pariwisata dan Ekonomi Kreatif Provinsi Banten Tahun 2018, serta dokumen pendukung lainnya

\section{Teknik Pengumpulan Data}

Pengumpulan data dilakukan melalui teknik survey, wawancara, dokumentasi, dan studi pustaka. Instrumen penelitiannya yaitu pedoman wawancara. Teknis analisis data dalam penelitian ini menggunakan model analisis interaktif Miles dan Huberman melalui 3 tahap, yaitu reduksi data, penyajian data, dan penarikan kesimpulan (Sugiyono, $2012: 301)$

\section{Prosedur Pengolahan Data}

Yang menjadi responden penelitian adalah Dinas Perindustrian dan Perdagangan Provinsi Banten dan Biro Bina Perekonomian SETDA Provinsi Banten

\section{Pemeriksaan Keabsahan Data}

Untuk memeriksa keabsahan data, penulis menggunakan uji validitas internal (credibility) yaitu melalui kepercayaan terhadap ucapan yang diungkapkan oleh responden sebagai informan, uji validitas eksternal (transferability) yaitu dilakukan dalam konteks (setting) tertentu yang dapat ditransfer ke subyek lain yang memiliki tipologi yang sama, uji reliabilitas (dependentbility) yaitu dengan cara mengecek konsep rencana penelitiannya dengan teknik pengumpulan data dan pengintepretasiannya, dan uji obyektivitas (confirmability) yaitu melalui kesepakatan banyak pihak dalam hal ini 2 dinas yaitu Biro Bina Perekonomian SETDA Provinsi Banten dan Dinas perindustrian dan perdagangan Provinsi Banten.

Untuk Uji validitas internal (credibility), penulis melakukan 1) Perpanjangan pengamatan melalui terjun langsung ke lokasi penelitian tidak hanya 1 kali tetapi beberapa kali, 2) Triangulasi yaitu melalui pengecekan data dari berbagai sumber (2 dinas), berbagai cara, dan berbagai waktu (perbandingan tahun). 3) Diskusi dengan teman yang memiliki pemahaman tentang industri kreatif, 4) Menggunakan bahan referensi yaitu menggunakan pendukung rekaman wawancara untuk membuktikan data penelitian, 5) Mengadakan member check yaitu dengan cara mengklarifikasi data kepada pemberi data agar data benar-benar valid. 


\section{Teknik Analisis Data}

Dalam penelitian ini, Teknik analisis data yang dipilih adalah analisis data model Milles dan Huberman, yang meliputi: (1) reduksi data yaitu data yang diperoleh di lapangan kemudian dirangkum kemudian dipilih hal-hal yang pokok dan yang penting dan membuang data yang tidak diperlukan, (2) display/penyajian data yaitu menguraikan data yang ditemukan di lapangan secara singkat dalam bentuk naratif baik melalui tabel maupun bagan, dan (3) mengambil kesimpulan lalu memverifikasi yaitu menyimpulkan data yang didukung oleh bukti-bukti yang valid dan kembali lagi ke lapangan untuk mengumpulkan data tambahan sebagai kesimpulan akhir laporan.

\section{Hasil dan Pembahasan \\ Perkembangan Industri Kreatif Berbasis Syariah di Wilayah Propinsi Banten}

Industri Kreatif berbasis Syariah di Provinsi Banten belum ada, namun Pemerintah memiliki wacana untuk regulasi dan pemetaan pengembangan Industri Kreatif berbasis syariah di Provinsi Banten. Seperti yang diungkapkan oleh Bu Santi, koordinator Biro Bina Perekonomian Setda Provinsi Banten yang mengatakan bahwa "...belum punya...masih merupakan wacana dan saya sedang menyusun rangka kebijakan industri kreatif berbasis syariah". Kemudian diungkapkan pula oleh Bapak Rudiansyah, Kepala Bidang Industri Dinas Perindustrian dan Perdagangan Provinsi Banten yang mengatakan bahwa "...belum memiliki industri kreatif berbasis syariah, karena kami baru akan merumuskan kebijakan kawasan industri Halal seperti yang tertera di Rencana Kebijakan 20 tahun ke depan”.

Menurut Pak Mulyadi, Kasi Perencanaan dan Pengembangan Industri di Dinas Industri dan Perdagangan Provisi Banten mengatakan bahwa "Industri Syariah sebenarnya sudah ada misalnya produk kuliner yang halal dan fashien yang halal juga (baju muslim) tetapi karena payungnya belum ada maka pengembangannya belum jelas ke arah mana. Nah, Untuk menuju ke tahap Industri berbasis syariah, yang perlu kami lakukan yaitu menyiapkan sertifikasi halal, mengarahkan para industri kreatif ke pembiayan-pembiayaan yang syariah (akadnya syariah), baru pelaksanaannya mengikuti regulasi syariah yang sudah disusun nanti".

Dari pernyataan diatas, jelaslah bahwa Provinsi Banten memiliki rencana untuk mengimplementasikan Industri Kreatif berbasis syariah. Ditambah lagi, Sejarah Banten dapat menjadi salah satu magnit bagi pengembangan ekonomi kreatif berbasis syariah. Selain itu, Visi Misi Propinsi Banten, salah satunya adalah berakhlakul karimah artinya pemberdayaan ekonomi umat. Ekonomi umat salah satunya adalah dengan pemberdayaan pondok pesantren melalui entrepreneur sehingga dapat menciptakan santripreneur. Di Pondok pesantren ini, nantinya bisa menjadi pusat unggulan produk dan pusat peradaban Islam. Hal ini senada dengan yang dikatakan oleh Bapak Rudi yaitu "Provinsi Banten memiliki 33.000 Pondok pesantren dan ini merupakan jumlah terbesar di Indonesia yang merupakan Aset utama dalam pelaksanaan Industri Kreatif berbasis syariah. Sehingga untuk target pelaksanaan Industri Kreatif berbasis syariah kedepannya melalui pemberdayaan umat di pondok pesantren. Diharapkan perekonomian masyarakat di sekitar pondok pesantren bisa meningkat, dan tentunya syariat islam untuk perekonomian bisa di implementasikan". 
Pelaku usaha kreatif di Provinsi Banten berdasarkan data dari Biro Bina Perekonomian Provinsi Banten ada sebanyak 144 pelaku usaha kreatif, berupa 14 usaha kreatif di bidang fashion, 24 usaha kreatif di bidang kriya, 57 usaha kreatif di bidang kuliner, 3 usaha kreatif di bidang seni rupa, 5 usaha kreatif di bidang aplikasi game dan developer, 3 usaha kreatif di bidang arsitektur, 5 usaha kreatif di bidang desain dan komunikasi, 6 usaha kreatif di bidang seni pertunjukkan, 9 usaha kreatif di bidang radio, 3 usaha kreatif di bidang photography, 1 usaha kreatif di bidang film dan animasi, 5 usaha kreatif di bidang periklanan, usaha kreatif di bidang desain dan produk, 7 usaha kreatif di bidang penerbitan dan 7 usaha kreatif di bidang desain interior yang tersebar di kabupaten/kota di Provinsi Banten.

Namun, menurut data Dinas Perindustrian dan Perdagangan dari 14 usaha kreatif, yang dijadikan komoditi utama Industri Prioritas berdasarkan RPIP yaitu Kerajinan, Fashion dan Animasi. Hal ini senada dengan yang diungkapkan oleh Bapak Rudy yang mengatakan bahwa "...Sektor yang paling dominan di Provinsi Banten yaitu kerajinan, fashion, animasi, dan kuliner". Tentunya dalam pengembangannya didasarkan pada era digital dan OVOP yaitu One Vilage One Product. Dimana, kesuksesan OVOP harus didukung oleh 3 aspek dasar yaitu Lokalitas produk mampu memenuhi pasar global, Masyarakatnya mampu bekerja secara mandiri, dan SDM memiliki mental siap dididik dan dibina.

Menurut Pa Rudy pula bahwa "Pengembangan industri kreatif di Provinsi Banten lebih ke arah pengembangan produk unggulan yang terakomodir oleh komoditas produk dan sentra yang dikembangkan melalui OVOP. Kategori produk OVOP yaitu Makanan ringan, Minuman sari buah dan sirup buah, Kain tenun, Batik, Kerajinan anyaman, dan Kerajinan gerabah. Sedangkan Kriteria Sentra yaitu Produksi kontinyu dan konsisten, Memiliki keunikan dan berkearifan lokal, Berpotensi ditingkatkan mutunya, Berpotensi untuk diekspor, dan Minimal 10 IKM dgn produk sama. Dasar hukum peningkatan produk unggulan daerah yaitu Inpres no.6 th. 2007 tentang Kebijakan Percepatan Pengembangan Sektor Riil dan Pemberdayaan Usaha Mikro, Kecil, dan Menengah, Inpres no.5 th. 2008 tentang Fokus Program Ekonomi th. 2008-2009, Permen Perindustrian no. 78/M-IND/PER/9/2007 tentang Peningkatan Efektivitas Pengembangan IKM melalui pendekatan OVOP, dan Permendagri No 9 Tahun 2014 Tentang Pud.

Program Ovop merupakan program Insentif Pemerintah. Dimana diperuntukkan untuk Perusahaan yang memiliki niat sungguh-sungguh untuk Maju dan Berkembang, Memperbaiki Produk dan Kualitasnya, serta Masuk Pasar Global, karenanya Perusahaan Wajib Mendaftar Ikut Ovop. Program Pembinaannya berupa Pemberian pendidikan dan pelatihan, Pemberian bantuan sarana produksi, dan Keikutsertaan dalam promosi dan pemasaran.

Arah pengembangan ekonomi kreatif di Provinsi Banten mengacu pada Visi Misi Ekonomi Kreatif Indonesia hingga tahun 2025, serta Instruksi Presiden No 5 tahun 2009 yaitu Peningkatan jumlah Sumber Daya Manusia (SDM) kreatif yang berkualitas secara berkesinambungan, Peningkatan jumlah dan perbaikan kualitas lembaga pendidikan dan pelatihan formal dan informal yang mendukung penciptaan insan kreatif dalam pengembangan ekonomi kreatif, Peningkatan penghargaan kepada insan kreatif oleh pemerintah, Peningkatan jumlah wirausahawan kreatif, Penciptaan database dan jejaring insan kreatif di dalam maupun di luar negeri, Peningkatan daya Tarik industry, 
Peningkatan efesien serta produktivitas industry untuk meningkatkan keunggulan komparatif, Peningkatan inovasi bermuatan local, untuk menciptakan keunggulan kompetitif, Pembentukan basis-basis teknologi pendukung industry di bidang ekonomi kreatif menuju klaster teknologi, Penguatan kapasitas penguasaan teknologi dan kemampuan pemanfaatan computer di bidang ekonomi kreatif, Penguatan iklim usaha kondusif bagi investasi teknologi pendukung ekonomi kreatif, dan Peningkatan kemampuan SDM untuk memanfaatkan bahan baku yang berasal dari alam. Sedangkan Strategi Kebijakan percepatan pembangunan Industri di Provinsi Banten melalui Pembangunan Sumber Daya Industri, Pembangunan Sarana dan Prasarana Industri, Pemberdayaan Industri, dan Pengembangan IKM.

Pengembangan yang dilakukan oleh Pemerintah Provinsi Banten baik Arah maupun Strategi sesuai dengan yang dirancang oleh Departemen Perdagangan yang mengatakan bahwa pengembangan industri kreatif menitik beratkan pada lapangan usaha kreatif dan budaya (creative cultural industry), lapangan usaha kreatif (creative industry), dan Hak Kekayaan Intelektual seperti hak cipta (copyright industri). Pengembangan ini diharapkan memberikan dampak positif pada kehidupan sosial, iklim bisnis, peningkatan ekonomi, dan juga pada pencitraan di kawasan Banten.

Kaitannya dengan Syariah, diharapkan Perkembangan Industri Kreatif Berbasis Syariah di Propinsi Banten akan selalu menitik beratkan pada prinsip-prinsip ekonomi syariah yaitu bahwa Sumber Daya yang dimiliki adalah titipan Allah SWT, sehingga harus dengan kejujuran dalam pengelolaannya karena kita harus yakin akan penentuan di hari akhir. Selain itu Ekonomi Syariah mengutamakan kepentingan orang banyak, menerapkan kegiatan jual beli yang islami, adil, halal dan tidak merugikan salah satu pihak, dan melarang adanya riba dalam segala macam bentuk. Intinya pengembangan industri kreatif berbasis syariah adalah menerapkan syariat islam dengan niat ibadah sehingga akan selalu memperoleh Ridho Allah SWT.

Langkah yang bisa pemerintah lakukan saat ini untuk perumusan regulasi pengembangan kawasan industri syariah adalah melihat dan mengkaji batasan-batasan halal dalam syariat islam yang hakiki. Sehingga regulasi yang tersusun akan mencerminkan syariat islam seutuhnya. Selain itu, mencari dukungan penuh dari pemerintah pusat agar regulasi yang sudah tersusun dapat dipayungi oleh pemerintah dengan jelas dan tegas.

\section{Model Pengembangan Industri Kreatif Berbasis Syariah di Propinsi Banten}

Model Pengembangan Industri Kreatif berbasis syariah di Provinsi Banten bisa mengoptimalkan bentuk bangunan yang sudah ada yaitu terdiri dari pondasi, bangunan, dan tap di tambahkan pada batasan-batasan syariat islami. Untuk Pondasinya berupa insan kreatif, untuk pengembangan insan yang kreatif pemerintah mengadakan pelatihanpelatihan untuk meningkatkan pengetahuan dan kreatifitas. Sedangkan pilar utamanya terdiri dari Industri, Teknologi, Sumberdaya Alam, Kelembagaan, dan Lembaga Keuangan. Tap disini adalah aktor utama, yang terdiri dari cendikiawan/ masyarakat, pelaku bisnis, dan pemerintah daerah. Semua bagian dari pondasi bangunan tersebut harus berdasarkan pada syariat islam.

Sebagai daya dukung pelaksanaannya bisa mengoptimalkan kerja sama antara pihak akademisi, bisnis, dan pemerintah atau biasa disebut sebagai triple helix. Pemerintah memiliki peran sebagai Katalisator dan Fasilitator serta Regulator. Katalisator 
dan Fasilitator, dimaksudkan bahwa pemerintan Provinsi Banten berperan dalam memberi rangsangan, tantangan dan dorongan agar ide-ide bisnis ekonomi kreatif berbasis syariah terus berkembang. Sebagai katalisator pemerintah daerah diharapkan berperan memberdayakan komunitas kreatif untuk lebih produktif tidak hanya konsumtif, memberikan penghargaan bagi pelaku individu maupun kelompok kreatif, prasarana intelektual (perlindungan hak kekayaan intelektual, internet cepat), dan permodalan termasuk modal ventura atau modal bergulir (revolving capital) dengan cara merintis hubungan dengan kalangan perbankan dan lembaga keuangan non bank yang berbasis syariah. Sebagai fasilitator pemerintah daerah melakukan fasilitas pembentukan forum ekonomi kreatif, fasilitas pengembangan pendidikan dan pelatihan kewirausahaan kreatif, dan penyediaan ruang publik sebagai media bagi masyarakat untuk berkumpul, alih pengatahuan, tukar infomasi dan menyalurkan kreatifitas. Sedangkan Regulator, dimaksudkan bahwa pemerintah Provinsi Banten berperan untuk membuat kebijakankebijakan yang berbasis syariah yang dapat menciptakan iklim usaha yang kondusif bagi pengembangan ekonomi kreatif terutama kebijakan yang terkait dengan sumberdaya manusia, industry, sumberdaya alam, dan teknologi.

Pelaku bisnis memiliki peranan dalam hal penciptaan produk dan jasa kreatif yang Halal, pasar baru yang dapat menyerap produk dan jasa yang dihasilkan serta penciptaan lapangan kerja bagi individu-individu kreatif dan tenaga kerja pendukung lainnya. Pelaku bisnis juga memiliki peranan dalam membentuk komunitas dan entrepreneur kreatif, yaitu sebagai motor penggerak dalam sharing pemikiran, alih pengetahuan, bimbingan bisnis dan pelatihan manajemen pengelolaan usaha di bidang ekonomi kreatif.

Peran Akademisis sebagai agen penyerbarluasan dan pengimplementasian ilmu pengetahuan, seni dan teknologi serta membentuk nilai-nilai yang konstruktif bagi pengembangan ekonomi kreatif di masyarakat Provinsi Banten yang berdasarkan pada nilai-nilai islami. Sehingga dapat mendorong lahirnya generasi-generasi yang memiliki pola pikir kreatif untuk mendukung tumbuhnya karsa dan karya ekonomi kreatif berbasis Syariah. Para Akademisi bisa melakukan penelitian dan pengabdian tentang implementasi industri kreatif berbasis syariah di wilayah Provinsi Banten, yang nantinya hasil kajiannya dapat di jadikan sebagai bahan masukan tentang kebijakan-kebijakan pengembangan ekonomi kreatif berbasis syariah, dan menghasilkan teknologi yang dapat mendukung cara kerja dan penggunaan sumberdaya yang efesien dan mengandung unsur halal, serta dapat menjadikan usaha ekonomi kreatif berbasis syariah yang kompetitif.

\section{KESIMPULAN}

Berdasarkan pada data penelitian, maka dapat penulis simpulkan bahwa Perkembangan Industri Kreatif Berbasis Syariah di Wilayah Propinsi Banten masih dalam tahap penyusunan rancangan regulasi dan kebijakan kawasan industri Halal. Namun secara tidak langsung teknik pelaksanaan industri kreatif yang berdasarkan syariah sudah berjalan yaitu untuk sektor kuliner dan fashion (baju muslim). Hanya saja mereka tidak memiliki label halal serta belum ada regulasi yang memayunginya. Namun, untuk target kedepannya, Pengembangan Industri Kreatif Berbasis Syariah di Wilayah Propinsi Banten lebih ke arah pemberdayaan pondok pesantren melalui entrepreneur sehingga dapat menciptakan santripreneur. Sehingga nantinya, pondok pesantren bisa menjadi pusat unggulan produk dan pusat peradaban Islam di Provinsi Banten. 
Model Pengembangan Industri Kreatif berbasis syariah di Provinsi Banten berbentuk bangunan yaitu terdiri dari pondasi, bangunan, dan tap yang berdasarkan pada batasan-batasan syariat islami. Untuk Pondasinya berupa insan kreatif, untuk pengembangan insan yang kreatif pemerintah mengadakan pelatihan-pelatihan untuk meningkatkan pengetahuan dan kreatifitas. Sedangkan pilar utamanya terdiri dari Industri, Teknologi, Sumberdaya Alam, Kelembagaan, dan Lembaga Keuangan. Tap disini adalah aktor utama, yang terdiri dari cendikiawan/ masyarakat, pelaku bisnis, dan pemerintah daerah. Semua bagian dari pondasi bangunan tersebut harus berdasarkan pada syariat islam. Sebagai daya dukung pelaksanaannya bisa mengoptimalkan kerja sama antara pihak akademisi, bisnis, dan pemerintah atau biasa disebut sebagai triple helix. Dimana, semua peran diatas harus berlandaskan pada prinsip-prinsip ekonomi syariah yaitu Sumber Daya yang dimiliki adalah titipan Allah SWT sehingga harus dengan kejujuran dalam pengelolaannya karena kita harus yakin akan penentuan di hari akhir, mengutamakan kepentingan orang banyak, menerapkan kegiatan jual beli yang islami, adil, halal dan tidak merugikan salah satu pihak, dan melarang adanya riba dalam segala macam bentuk.

\section{REFERENSI}

Abdur Rohim Boy Berawi, Deputi Riset, Edukasi, dan Pengembangan Badan Ekonomi Kreatif (BEKRAF) dalam Rakor Rencana Program Pengembangan Ekonomi Kreatif yang digelar BEKRAF di Ambon, Maluku, Selasa (1 Maret 2016). "Industri Kreatif Sumbang Rp 642 Triliun dari Total PDB RI" .Tempo.Co.Jakarta. Tertanggal 02 Maret 2016 pukul 18:38 WIB. Alamat : https://m.tempo.co/read/news/2016/03/02/090750007/industri-kreatif-sumbang-rp-642triliun-dari-total-pdb-ri. Diunduh pada tanggal 10 Mei 2017 pukul 22.00 WIB.

Ahmad Muhammad Al-assal dan Fathi Ahmad Abdul Karim. 1980. Sistem Ekonomi Islam, Prinsip-Prinsip Dan Tujuan-Tujuannya. Surabaya: PT Bina Ilmu.

Aisyah, Irwan, dan Ainul. 2013. Pengembangan Industri Kreatif Di Kota Batu (Studi Tentang Industri Kreatif Sektor Kerajinan Di Kota Batu). Jurnal Administrasi Publik (JAP) Vol 2 N0 2 Hal 281-286.

Al Arif, M. Nur Rianto dan Euis Amalia. 2010. Teori Mikroekonomi: Suatu Perbandingan Ekonomi Islam dan Ekonomi Konvensional. Jakarta : Kencana.

Creative Economy. (2013). Alamat : http://indonesiakreatif.net/creative-economy.

Departemen Perdagangan Republik Indonesia. 2008. Pengembangan Ekonomi Kreatif Indonesia 2025 : Rencana Pengembangan Ekonomi Kreatif Indonesia 20092025. Jakarta: Departemen Perdagangan.

Dunn, William N. (2003). Analisis Kebijakan Publik. Yogyakarta: Gadjah Mada University Press.

Haidar Tsany Alim, Andi Okta Riansyah, Karimatul Hidayah, Ikhwanul Muslim, Adityawarman. 2015. Analisis Potensi Pariwisata Syariah Dengan Mengoptimalkan Industri Kreatif Di Jawa Tengah Dan Yogyakarta. Jurusan Akuntansi Fakultas Ekonomika dan Bisnis Universitas Diponegoro : Semarang. Artikel. Alamat : http://eprints.undip.ac.id/45828/1/Artikel.pdf 
HIPMI : Industri Kreatif harusnya dapat Insentif. Palapa News. Tertanggal 16 / 03 / 2016 jam 2:14 WIB. Alamat : http://palapanews.com/2016/03/16/hipmi-industri-kreatifharusnya-dapat-insentif/. Di unduh pada tanggal 10 Mei 2017 pukul 21.00 WIB.

Hendang Setyo Rukmi, Lisye Fitria, Fajri Zonda. 2012. Studi Tentang Kondisi Industri Kreatif Permainan Interaktif Di Kota Bandung Berdasarkan Faktor-Faktor Yang Dipersepsikan Penting Oleh Produsen Dan Konsumennya. Jurnal ITENAS Rekayasa No 1 Vol XVI Januari 2012. Bandung : Itenas

Kementerian Koperasi dan Usaha Kecil dan Menengah Republik Indonesia. 2010. Model Pembiayaan Non Bank/ Lembaga Pengelola Dana Bergulir (LPDB) Untuk Industri Kreatif. Jakarta : Deputi Bidang Pembiayaan

Mandra dan M. Sandy. 2015. Ekonomi Kreatif: Rencana Pengembangan Kuliner Kuliner Nasional 2015-2019. Jakarta : PT Republik Solusi

M. A Mannan. 1992. Ekonomi Islam: Teori dan Praktek. Jakarta: PT. Intermasa.

Muhammad, Manajemen Bank Syariah, ( Yogyakarta : (UPP) AMP YKPN,tt), cet-1

Muhlisin Riadi. 2017. Pengertian, Tujuan, Prinsip dan Manfaat Ekonomi Syariah. Alamat https://www.kajianpustaka.com/2016/09/pengertian-tujuan-prinsip-dan-manfaatekonomi-syariah.html. di unduh pada tanggal 15 Mei 2017 pukul 11.00 WIB

Pajak Diturunkan, Pelaku UKM Optimistis Daya Saing Akan Naik. 2016. tertanggal 25 \begin{tabular}{ll|lll} 
November & 2016 & 18:29
\end{tabular} https://m.tempo.co/read/news/2016/11/25/090823216/pajak-diturunkan-pelaku-ukmoptimistis-daya-saing-akan-naik di unduh pada tanggal 15 Mei 2017 pukul 11.00 WIB

Pemerintah Provinsi Banten. 2017. Laporan Akhir tentang Kebijakan dalam Menumbuhkan kembangkan Ekonomi Kreatif di Provinsi Banten. Banten : Biro Bina Perekonomian Setda Provinsi Banten

Pemerintah Provinsi Banten. 2017. Laporan Akhir Penyusunan Profil Kebijakan Pariwisata dan Ekonomi Kreatif. Banten : Biro Bina Perekonomian Setda Provinsi Banten

Pemerintah Provinsi Banten. 2017. Laporan akhir Profil Kebijakan Pariwisata dan Ekonomi Kreatif Provinsi Banten. Banten : Biro Bina Perekonomian Setda Provinsi Banten

Pramdia Arhando Julianto. 2016. Ditjen Pajak Gelar Sosialisasi "Tax Amnesty" untuk UMKM. Kompas.com. Tertanggal 05 oktober 2016 Pukul 17:02 WIB. Alamat : http://bisniskeuangan.kompas.com/read/2016/10/05/170226926/ditjen.pajak.gelar.sosialisa si. tax.amnesty.untuk.umkm. Di unduh pada tanggal 10 Mei 2017 pukul 21.00 WIB

Pusat Pengkajian dan Pengembangan Ekonomi Islam (P3EI). 2012. Ekonomi Islam. Jakarta: PT Raja Grafindo Persada.

Rahman, Afzalur. 1995. Doktrin Ekonomi Islam Jilid I. Yogyakarta: Dana Bhakti Wakaf.

Reni dan Nova. 2015. Peran Pemerintah Dan Akademisi Dalam Memajukan Industri Kreatif Kasus Pada UKM Kerajinan Sulaman Di Kota Pariaman. Hasil Seminar 
Tri Harjawati

Nasional Ekonomi Manajemen Dan Akuntansi (SNEMA) Fakultas Ekonomi Universitas Negeri Padang .

Rudiansyah Thoib. 2018. Potensi Industri Unggulan di Provinsi Banten RPIP 2018-2038, Rapat Penyusunan Kebijakan Penetapan Produk Unggulan Daerah/ KPJU Banten. Dinas Perindustrian dan Perdagangan Provinsi Banten.

Rudiansyah Thoib. 2018. Rancangan Perda, Rencana Pembangunan Industri Provinsi (RPIP) Banten dalam Memihakki Usaha Kecil. Dinas Perindustrian dan Perdagangan Provinsi Banten.

Sugiyono. 2012. Metode Penelitian Kuantitatif, Kualitatif dan R\&D (Qualitative And Quantitative Research Methods). Bandung: Alfabeta.

Sugiono. 2016. Metode Penelitian Kombinasi (Mixed Methods). Bandung: Alfabeta.

Sudarsono, M.B, Hendri. 2002. Pengantar Ekonomi Mikro Islam. Yogyakarta, Ekonosia.

Tri Harjawati. 2016. Peran Pemerintah dalam Pengembangan Lembaga Pembiayaan di Sentra Industri Berbasis Ekonomi Kreatif (Studi Kasus Industri Kuliner Kota Tangerang Selatan). PUSLITPEN LP2M UIN Syarif Hidayatullah Jakarta. Tidak di Publikasikan.

Zainuddin Ali. 2008. Hukum Ekonomi Syariah. Jakarta: Sinar Grafika Offset. 